\title{
OS APURINÃ E A ÚLTIMA FRONTEIRA DO ESTADO BRASILEIRO
}

\section{THE APURINÃ AND THE LAST FRONTIER OF THE BRAZILIAN STATE}

\author{
LOS APURIÑA Y LA ÚLTIMA FRONTERA DEL ESTADO BRASILEÑO
}

\author{
Rogério Sávio Link ${ }^{1}$
}

\begin{abstract}
Resumo: No final do século XIX até o início do século XX, a ocupação dos vales dos rios Juruá e Purus conforma efetivamente a última fronteira do expansionismo luso-brasileiro. Esse último fôlego expansionista foi impulsionado pela migração de nordestinos que fugiram das secas que assolaram o Nordeste em 1825, em 1846 e em 1877. Internacionalmente, esse processo também foi estimulado pelo contexto da Segunda Revolução Industrial que demandava a borracha produzida a partir da seiva da seringueira (hevea brasiliensis). Com este artigo, pretendo lançar um olhar sobre um conjunto de fontes que descrevem os primeiros anos de ocupação do Médio Purus, a saber, relatórios de viagens das primeiras expedições e escritos dos primeiros colonizadores. Meu objetivo aqui é descrever os primeiros anos de contato com os povos indígenas da região, focando especialmente nos Apurinã e, se possível, entrever nesses escritos a agência histórica indígena.
\end{abstract}

Palavras chaves: Apurinã, Colonização, Amazônia, Purus, indígena.

Abstract: At the end of the 19th century until the beginning of the 20th century, the occupation of the Juruá and Purus river valleys effectively formed the last frontier of brazilian expansionism. This last expansionary impulse was driven by the migration of Northeasterners who fled the droughts that devastated the Northeast in 1825, in 1846 and in 1877 . Internationally, this process was also stimulated by the context of the Second Industrial Revolution that demanded rubber produced from the sap of the rubber tree (hevea brasiliensis). With this article, I intend to take a look at a set of sources that describe the early years of occupation of the Middle Purus, namely, travel reports of the first expeditions and writings of the early settlers. My purpose here is to describe the first years of contact with the indigenous peoples of the region, focusing especially on the Apurinã and, if possible, to glimpse in those writings the indigenous historical agency.

Keywords: Apurinã, Colonization, Amazon, Purus, indigenous.

Resumen: A finales del siglo XIX hasta principios del siglo XX, la ocupación de los valles de los ríos Juruá y Purus conforma efectivamente la última frontera del expansionismo lusobrasileño. Este último aliento expansionista fue impulsado por la migración de nordestinos que huyeron de las sequías que asolaron el Nordeste en 1825, en 1846 y en 1877. Internacionalmente, ese proceso también fue estimulado por el contexto de la Segunda Revolución Industrial que demandaba el caucho producido a partir de la savia de goma (Hevea

\footnotetext{
${ }^{1}$ Doutor em Teologia pela Faculdades EST (2008). Doutor em História pela UFRGS (2016), Pós-doutor em História Indígena pela UFGD. O presente trabalho foi realizado com apoio do CNPq, Conselho Nacional de Desenvolvimento Científico e Tecnológico - Brasil. Este artigo é parte dos resultados de um projeto de pesquisa de doutoramento em História Indígena defendido em 2016 na UFRGS e de posterior pesquisa de pós-doutoramento feita na UFGD. Ele analisa as principais fontes históricas que tratam sobre a colonização do Médio Rio Purus na segunda metade do século XIX.
}

Fronteiras: Revista de História | Dourados, MS | v. 19 | n. 33 |p. 11 - 42 | Jul. / Dez. 2017 
brasiliensis). Con este artículo, pretendo echar un vistazo a un conjunto de fuentes que describen los primeros años de ocupación del Medio Purus, a saber, informes de viajes de las primeras expediciones y escritos de los primeros colonizadores. Mi objetivo aquí es describir los primeros años de contacto con los pueblos indígenas de la región, enfocando especialmente en los Apuriná y, si es posible, entrever en esos escritos la agencia histórica indígena.

Palabras claves: Apurinã, Colonización, Amazonia, Purus, indígena.

\section{As fontes mais antigas que tratam sobre os Apurinã}

As fontes mais antigas sobre a região mais próxima aos Apurinã são o relato do descobrimento do Rio das Amazonas do padre Christoval de Acuña (1641), o diário e um mapa do jesuíta Samuel Fritz (1697) e um mapa de Charles-Marie de La Condamine (1743-1744). No entanto, essas fontes não trazem informações sobre o Médio Purus e seus habitantes. Apenas observo aqui que o padre Acuña teria batizado o Purus como Yanapuary; o nome teria sido dado em referência a um povo que habitaria a embocadura do rio (CASTELO BRANCO, 1958, p. 12). Os mapas, tanto de Fritz (figura 1) quanto de La Condamine (figura 2), não obstante, são aqui tomados como um contraponto dos mapas mais recentes. Nesses mapas, não existem informações significativas acerca do Rio Purus ou de seus habitantes. Mas o dado mais significativo para nosso objeto em questão diz respeito à mudança de nome do rio. Enquanto no mapa de Fritz o rio é denominado Cuchiuara (também Cuxiuara), no mapa de La Condamine ele já aparece como Purus. Essa diferença pode estar no fato de Fritz ter sido um missionário a serviço da coroa espanhola e, portanto, refletia o ponto de vista do lado espanhol. Condamine, por sua vez, um cientista e explorador francês a serviço da Real Academia das Ciências da França que esteve desde 1735 até 1744 na América do Sul como líder da Expedição Geodésica do Equador que tratava de medir os meridianos para descobrir a forma exata da Terra, parece registrar a ocupação de fato da coroa portuguesa. Por essa época, os portugueses mantinham o controle e exploravam regularmente a região, especialmente do Rio Negro e do Rio Branco onde tentavam utilizar as populações indígenas como "muralhas dos sertões" para impedir o avanço de outras nações europeias sobre a região (FARAGE, 1991). Condamine também construiu seu mapa deixando a versão de Fritz ao fundo, pois sua intenção era produzir um contraste, já que sua cartografia teria sido a primeira feita a partir de observações astronômicas. 
Figura 1: Mapa de Samuel Fritz de 1697

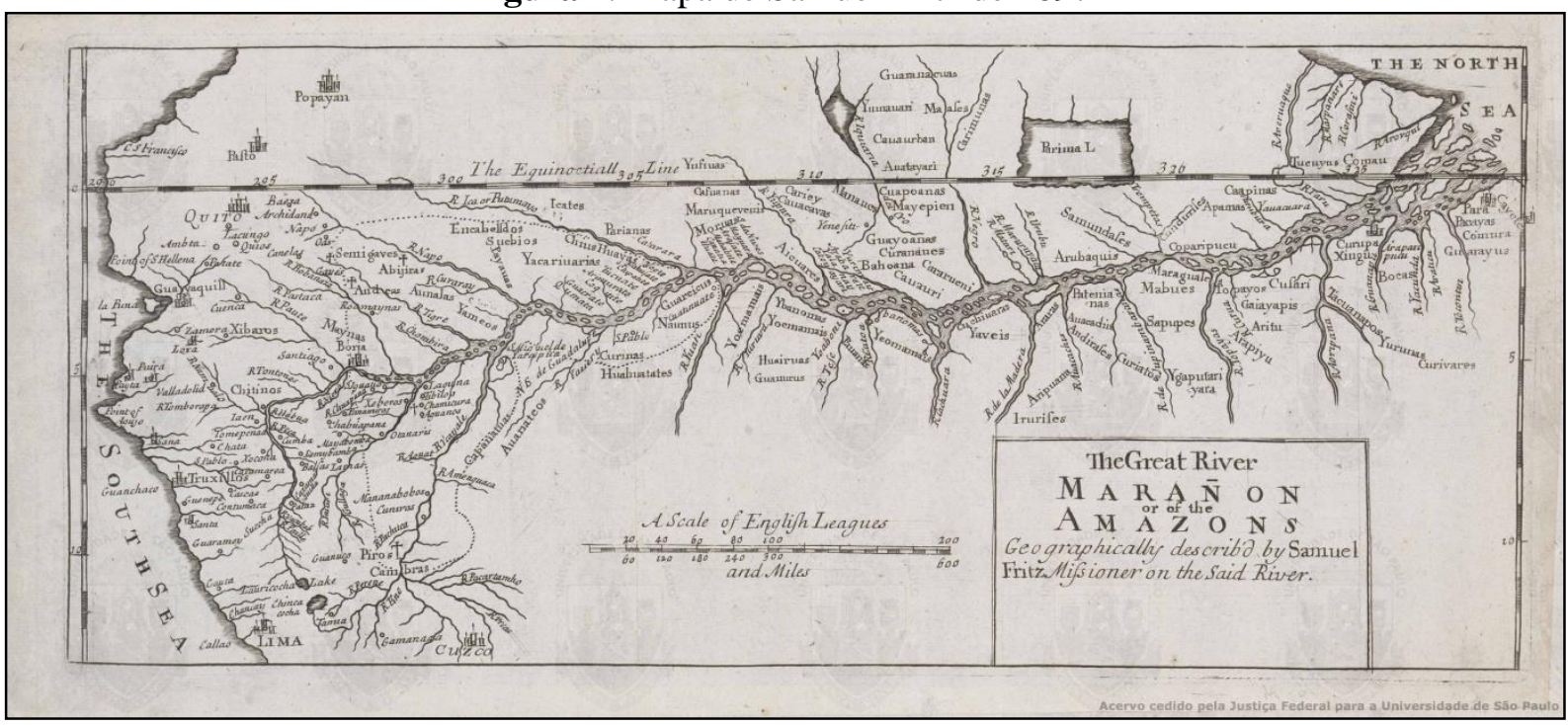

Fonte: Biblioteca Digital de Cartografia Histórica (Versão inglesa; impressão de 1732)

Figura 2: Mapa de Charles-Marie de La Condamine de 1743-1744

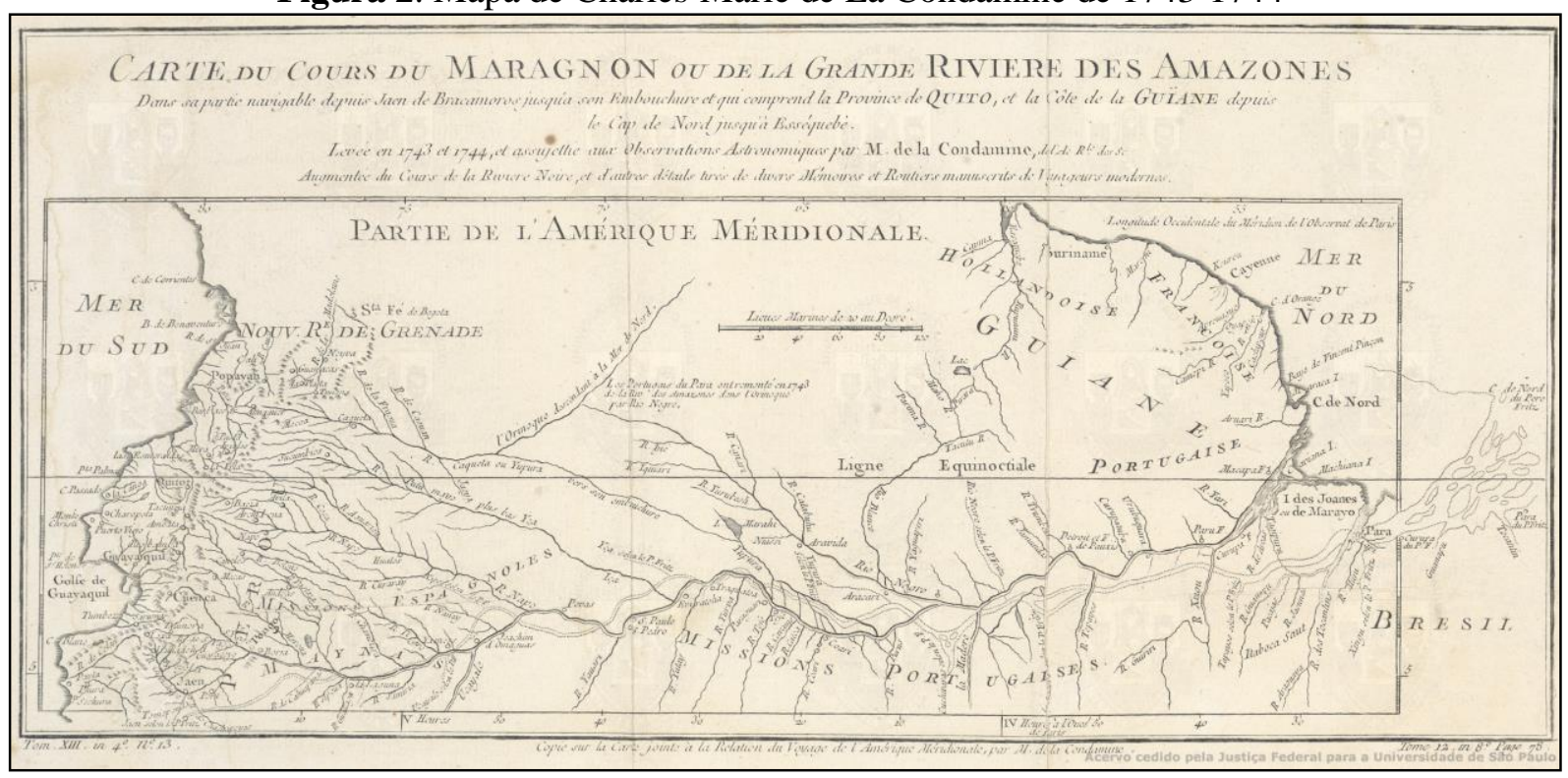

Fonte: Biblioteca Digital de Cartografia Histórica (Versão francesa; impressão de 1745)

Ainda do período colonial, existem alguns documentos no arquivo do Conselho Ultramarino que descrevem as disputas pelo território entre a coroa espanhola e a coroa portuguesa e que envolviam obviamente as populações indígenas. Como esses documentos são muito anteriores à ocupação do Rio Purus e não dizem respeito aos Apurinã diretamente, eles também não são aqui analisados. Mesmo assim, é possível tomar como hipótese que os Apurinã e os demais povos do Purus mantinham contatos esporádicos e obtinham ferramentas dos 
exploradores portugueses que se estabeleceram no Solimões. A região do Solimões foi efetivamente ocupada pelos portugueses no início do século XVIII e os documentos falam que era habitada pelos seguintes grupos: Nuruaques, Cauixanas, Jumanas, Passés, Uainumas, Catuquinas, Jamamadis, Pamanas, Júris e Jurimaguas, Tupebas ou Tapibás (SILVA, 2010, p. 225). É possível que sob a designação de alguns desses grupos possam estar presentes também os antepassados dos atuais Apurinã. Muitos povos indígenas demograficamente diminuídos pelos conflitos e pelas epidemias afastaram-se do Solimões ou foram incorporados às vilas erigidas pela administração portuguesa, como a vila de Ega, atual Tefé, localizada entre as embocaduras do Purus e do Juruá.

Já do período imperial, as fontes são mais abundantes. O século XIX é o século dos geógrafos, naturalistas e exploradores e a região amazônica esteve no centro do interesse de muitos deles. É a partir dessa época das viagens exploratórias que começa a ser esboçado o panorama das relações interétnicas do Purus (LAZARIN, 1981, p. 8), ou seja, o estado começa a delinear um processo de etnificação dos povos indígenas do Purus. Entendo etnificação como definido por Guillaume Boccara (2003, p. 90), ou seja, como um dos braços do processo de construção de identidade/etnicidade, como um movimento desde fora do grupo. O outro braço seria a etnogênese, como um movimento desde dentro; ainda que este conceito, como eu o entendo, já comporte o processo de etnificação. Nesse sentido, entre as décadas de 1840 e 1850 , o geógrafo, historiador e explorador britânico Clements Robert Markham esteve no Peru fazendo estudos sobre a civilização incaica. Os Andes e o Vale Amazônico estiveram no centro de seus interesses científicos. Embora não trate diretamente sobre os Apurinã, e por isso seus escritos não serão aqui estudados, seus trabalhos são fontes para o estudo dos povos Aruak das nascentes do Purus. De semelhante forma, o naturalista canadense Charles Frederick Hartt participou em cinco expedições pelo território brasileiro entre 1865 e 1878, ano em que veio a falecer no Rio de Janeiro a serviço do governo brasileiro. Suas anotações etnográficas e suas notas sobre a Língua Geral ou Tupi (1872) constituem-se em fontes importantes para o estudo do período. No entanto, Hartt também não traz informações a respeito dos Apurinã.

Destaque especial merecem os documentos de João Henrique de Matos e de João Wilkens de Mattos. O primeiro produziu em 1845 um importante relato, a partir de observações de primeira mão, sobre a situação da Província do Amazonas após a Cabanagem (1835-1840). Henrique de Matos foi nomeado, em 1841 pela Secretaria de Estados e Negócios Estrangeiros, “comissário da inspeção e exames dos pontos contestados pelo Governo de Sua Majestade 
Britânica". Seu relato foi publicado pela Revista do Instituto Histórico e Geográfico Brasileiro em 1979. Wilkens de Mattos, por sua vez, era delegado na Barra do Rio Negro (atual Manaus) e produziu seu relato - o qual também se encontra publicado na Revista do Instituto Histórico e Geográfico Brasileiro do ano de 1856 - sobre a situação dos postos missionários na província do Amazonas em 1855. Ambos os relatos, portanto, devem ser consultados.

Do período em que o Rio Purus começa a ser explorado mais sistematicamente, encontram-se os relatos de viajantes e exploradores como João Martins da Silva Coutinho e William Chandless. Silva Coutinho foi um geógrafo brasileiro pioneiro no Amazonas, participando de uma expedição científica promovida pelo Instituto Histórico (1862). Seus trabalhos e diários podem ser encontrados no Museu Paraense Emílio Goeldi. Os documentos de sua autoria que falam da exploração do Purus se encontram publicados na obra "O tratado Brasil-Peru: Documentos para a História do Acre” (2009a [1863], 2009b [1862], 2009c [1862], 2009d [1863]). Chandless, por sua vez, foi um geógrafo inglês que realizou viagem exploratória no Amazonas na década de 1860, descrevendo sua geografia, fauna, flora e habitantes. Entre junho de 1864 a fevereiro de 1865, fez uma viagem exploratória do Rio Purus (1866a) e de um de seu afluente o Rio Acre (1866b). Seus trabalhos foram publicados na revista da Royal Geographical Society e podem ser encontrados digitalizados na Internet. Os trabalhos tanto de Coutinho quanto de Chandless são fontes indispensáveis para tratar a história do Purus no século XIX. O naturalista alemão Gustav Wallis também acompanhou a expedição de Coutinho ao Purus em 1862, mas seus trabalhos foram mais sobre a flora e a fauna da região e excepcionalmente traz alguma informação sobre os Paumari (WALLIS, 1886). Coutinho (2009c: 249) diz que ele inclusive teria permanecido nas corredeiras do Hyutanahã - local mais ao sul que a expedição teria alcançado - para realizar observações e coletar material. Ehrenreich (1929, p. 292), no entanto, afirma que Wallis teria chegado até a embocadura do Rio Pauini. Por não trazer informações significativas sobre os Apurinã, a obra de Wallis não será aqui trabalhada.

Assim, as informações mais importantes sobre os Apurinã e sobre o Rio Purus proveem das expedições oficiais de reconhecimento que partiram desde Manaus. A primeira delas foi a de João Cunha Correa, ou João Cametá (1847?) como era mais conhecido, que teria ido até a embocadura do Ituxi (CHANDLESS, 1866 ${ }^{\mathrm{a}}$, p. 86), mas desconheço a existência de qualquer relatório produzido por esta expedição. Marco Antônio Lazarin (1981, p. 8s) vai afirmar que ele teria sido escolhido para a primeira expedição porque, como explorador das drogas dos 
sertões, tinha conhecimentos dos lagos e rios e da população do Baixo Purus. A segunda foi chefiada por Serafim da Silva Salgado em 1852 a mando do presidente da província do Amazonas. O relatório da viagem foi publicado em 1853 nos anexos das falas do presidente da província dirigidas à assembleia legislativa. Encarregado de chegar até uma povoação boliviana, em 10 de maio de 1852, Serafim partiu em duas canoas com uma esquadra de 13 soldados e 12 indígenas Mura, dos quais 8 desertaram no meio do caminho. No dia 30 de novembro, aportaram novamente em Manaus. Como perdeu seus remeiros indígenas, para prosseguir viagem, requisitou ajuda dos índios Purú-purú. O nome Purú-purú viria de um problema de pele encontrada entre muitos indígenas do Purús o que fazia com que eles ficassem cheios de pintas. Na língua geral, purú-purú significaria pintado. O nome do rio seria, portanto, uma derivação desse antigo etnônimo (LABRE, 1872, p. 9). Chandless (1866 a p. 92) afirma que os Paumari e os Juberi seriam subdivisões dessa antiga tribo cujo nome já não era mais usado em sua época. Ehrenreich (1891, p. 49) ainda afirma que eles seriam parentes dos "Arauá do Juruá" e que Martius já os havia descrito. Trata-se, portanto, de um povo pertencente à família Arawá; e, provavelmente, as fontes estão certas em afirmar que seriam os mesmos Paumari e Juberi.

Em seu relatório, Serafim diz ter chegado até os índios Cucama - provavelmente tratase dos atuais Manchineri, uma vez que ele subiu cerca de 27 dias de viagem acima do Rio Canaquiri (atual Rio Acre). Também porque, na única vez que o relatório traz alguma informação sobre os Apurinã, afirma que os Cucama seriam perseguidos por eles, pelos Kanamari e pelos Oainomaris (Uainamari), todos tidos como antropófagos e que faziam coalizões para atacá-los. Os limites dos territórios dos Kanamari e dos supostos Uainamari, que pode ser na verdade um grupo Apurinã, ficava nas imediações do Rio Iaco. Portanto, a expedição de Serafim esteve acima desse rio. Além disso, Serafim afirma que os Cucama faziam uso de vestimenta e conheciam algumas palavras do espanhol como acha (machado), macheta (terçado) e cuchillo (faca).

A terceira expedição foi chefiada em 1861 pelo prático (perito em navegação) Manoel Urbano da Encarnação - ou simplesmente Manoel Urbano como é mais conhecido. Ele foi encarregado pelo presidente da província Manoel Clementino Carneiro da Cunha de explorar o Purus com a finalidade de encontrar uma possível passagem para o Alto Madeira. Em sua expedição até o Alto Purus, também subiu o Rio Acre durante 20 dias. Na verdade, a partir dessa década, Urbano exploraria, oficialmente ou por conta própria, toda a extensão do Rio 
Purus que atualmente faz parte do território brasileiro e inúmeros outros rios e igarapés. Não existem relatórios, ou são ainda desconhecidos, que sejam de sua autoria. O único escrito é uma carta datada de 1882 que narra alguns costumes e crenças dos índios do Purus e que foi publicada pelo Boletim do Museu Paraense em 1902. No entanto, diferente das expedições anteriores, praticamente todas as informações presentes nos relatórios dos outros exploradores dependem diretamente dos conhecimentos de Urbano. Como um explorador que se estabeleceu no Purus para a exploração da borracha, Urbano se comunicava em várias línguas indígenas, inclusive em apurinã. Em sua segunda subida ao Purus, ele estabeleceu uma colocação nas barreiras do Hyutanahã abrindo um grande roçado com um grande número de Apurinãs e Juberis (COUTINHO, 2009b, p. 199).

Chandless (1866 ${ }^{\mathrm{a}}$, p. 86), uma das principais referências sobre o Purus e sobre as populações indígenas da região na segunda metade do século XIX, reconhece que a maior parte das informações que obteve sobre o Purus, sobre seus afluentes e sobre a população indígena advinha desse homem que ele classifica como um mulato, "um homem com pouca educação formal, mas com grande inteligência natural"².

Através de grande tato, firmeza e coragem ele adquiriu uma extraordinária influencia entre os índios do Purus, e está bem familiarizado com muitas tribos e seus idiomas. Eu falei muito sobre ele, porque um grande volume das informações que eu obtive, especialmente sobre os índios, foram recolhidas através dele; e absolutamente tudo o que é conhecido dos tributários do Purus, excetuando os três primeiros, é conhecido a partir de sua informação (CHANDLESS, $1866^{\mathrm{a}}$, p. 86) ${ }^{3}$.

De semelhante forma, os relatórios de Coutinho (2009a [1863], 2009b [1862], 2009c [1862], 2009d [1863]) também podem ser tidos como de coautoria de Urbano, pois as informações ali registradas proveem diretamente de seus conhecimentos. Em um ofício dirigido ao presidente da província do Amazonas em 1862, Coutinho (2009c, p. 248) afirma: “O prático Manoel Urbano prestou relevantes serviços, quer ministrando-me valiosas informações, pois é o maior conhecedor do Purus, quer facilitando a viagem, pela grande influência que goza entre os índios". Tal ofício tinha a finalidade de apresentar o relatório da expedição de 1862 e propor que Urbano fosse instituído como Inspetor dos Índios do Purus.

\footnotetext{
2 "a man of slight education, but great natural intelligence".

3 "By great tact, firmness, and courage he has acquired an extraordinary influence among the Indians of the Purûs, and is well acquainted with many tribes and their languages. I have said thus much about him, because a great deal of the information, especially about the Indians, which I have obtained has been gathered from him; and absolutely all that is known of the tributaries of the Purûs, excepting the first three, is known from his information".
}

Fronteiras: Revista de História | Dourados, MS | v. 19 | n. 33 |p. 11 - 42 | Jul. / Dez. 2017 
Apesar de velho, Coutinho diz que ele era um dos que mais trabalhava; inclusive no corte de lenha. Na verdade, essa teria sido a quarta expedição oficial a subir o Rio Purus na qual o governo da província enviou o vapor Pirajá para explorá-lo. Ela teria sido organizada a partir das informações prévias obtidas através dos conhecimentos desse caboclo com traços marcadamente negros nascido em Manacapuru e tido como o grande descobridor das terras acreanas. Por seu conhecimento, Urbano foi encarregado como chefe dessa expedição, da qual participou Coutinho e também o naturalista Gustav Wallis, mas os relatos são de autoria de Coutinho. Neste mesmo sentido, quando explorou os rios Mucuim e Ituxi em 1864, o relato oficial que deixou é também de autoria de Coutinho (1866[1865]). Tudo indica que Urbano teria requisitado ajuda dele para redigir o relatório ao presidente da província. Na presença de doutos letrados que registraram a história, o conhecimento prático tendeu a ser silenciado. No entanto, o conhecimento de Urbano sobre o Purus e seus habitantes era muito superior ao conhecimento dos homens de ciência. Assim, aqueles que levariam os créditos tiveram que registrar nas entrelinhas de seus escritos a contribuição decisiva dada por Manoel Urbano.

Outro personagem de grande influência na colonização do Rio Purus foi o Coronel Antonio Rodrigues Pereira Labre. A povoação de Labria, atual cidade de Lábrea, logo abaixo da boca do Rio Ituxi, foi fundada por ele em 1871 e batizada com seu nome numa forma de auto-homenagem. Labre teria chegado ao Purus por intermédio de um dos filhos de Manuel Urbano que o conduziu para a região (CASTELO BRANCO, 1958, p. 44). De autoria de Labre, existe um relato de notícias do Rio Purus (LABRE, 1872), um relato de uma exploração desde o Rio Madre de Deus até o Rio Acre (LABRE, 1888a) e um relato de exploração do Rio Ituxy (LABRE, 1888b). O primeiro foi escrito como um panfleto com claras intenções de atrair imigrantes para sua colônia em pleno território apurinã. Sua descrição dos índios da região, portanto, estão permeadas por seus próprios interesses econômicos em jogo. Seu interesse não é descrever os indígenas, mas de atrair imigrantes e, dessa forma, utilizando-se de sua imaginação e dados dispersos, mistura informações culturais e linguísticas de diferentes grupos para apresentar um índio genérico. De tal modo, suas informações a respeito dos povos indígenas do Purus devem ser relativizadas mais do que as informações de outros viajantes. Além disso, como ele mesmo observa, sua principal fonte é Chandless. Quanto ao segundo e ao terceiro artigos, foram palestras proferidas perante a Sociedade Geográfica do Rio de Janeiro da qual fora membro associado. Com essas exposições, a principal intenção de Labre é defender a abertura de uma estrada de ferro 
ligando as bacias do Rio Madeira e do Rio Purus, tendo como eixo central o povoado fundado por ele. Defendia, assim, que o empreendimento da estrada de ferro Madeira-Mamoré não deveria ser levado adiante e que em seu lugar se fizesse uma estrada Ligando Lábrea ao Rio Beni e ao Alto Rio Madeira e outro braço ligando Lábrea ao Médio Rio Madeira (LABRE, $1888^{a}$, p. 103). É nesse sentido que ele procurou abrir uma ligação entre o Purus e o Madeira através dos Campos Gerais do Puciari. O artigo sobre a exploração do trajeto entre o Rio Madre de Deus e o Rio Acre é um importante documento no qual Labre narra o encontro e a parceria que obteve de diversos povos dessa região. Já na exploração do Rio Ituxi, ele traz algumas informações mais relevantes para a história dos Apurinã e de outros povos que habitavam e habitam a região do Médio Rio Purus.

Há ainda outro conjunto de fontes importantes pelas suas contribuições etnográficas sobre o período: os trabalhos de Paul Ehrenreich e Joseph Beal Steere e extratos de cartas e relatórios produzidos por missionários da South American Missionary Society entre as décadas de 1870 e 1880. No entanto, essas fontes não serão aqui analisadas. Somente alguma informação parcial foi tomada para esclarecer alguma dúvida presente em outras fontes. Analisar essas fontes demandaria muitas laudas a mais, o que ultrapassaria os limites deste artigo. Existem outras fontes secundárias que aqui também não foram analisadas, a saber: Constant Tastevin e Paul Rivet (FAULHABER; MONSERRAT, 2008), Euclides Rodrigues da Cunha (1975 [1907]; 1909; 1905), Curt Nimuendajú (1955, 1981 [1944]),

Portanto, as principais fontes para o estudo dos Apurinã no final do século XIX proveem dos documentos de João Henrique de Matos e de João Wilkens de Mattos e das expedições de Urbano, Salgado, Coutinho, Chandless, Labre, Ehrenreich e Steere. No entanto, as fontes derivadas desses dois últimos pesquisadores não serão aqui analisadas. Desse modo, dando continuidade ao trabalho, depois de apresentar e fazer a crítica das fontes, passo agora a analisar o conteúdo relativo aos Apurinã que está presente nessas fontes.

\section{Os Apurinã que as fontes descrevem}

Até aqui me detive na apresentação e na crítica geral às fontes históricas sobre os Apurinã. Cheguei à conclusão de que as fontes indispensáveis são os relatos de Henrique de Matos, de Wilkens de Mattos, de Urbano, de Salgado, de Coutinho, de Chandless e de Labre. Os relatos de Labre diferenciam-se dos demais por serem escritos desde o ponto de vista de um 
colonizador. Também afirmei que os dados provenientes de Urbano - uma das principais fontes de informações linguísticas e etnográficas sobre os Apurinã e ele mesmo um colonizador estão dispersos de forma transversal nos relatos dos demais exploradores. Agora, pois, pretendo averiguar o que essas fontes dizem sobre o modo de vida e sobre a cultura apurinã. Além disso, também quero recolher informações que permitam verificar a ação e as intenções próprias dos povos indígenas do Purus no processo de exploração e colonização bem como o processo de etnificação e classificação dos povos indígenas presente nessas fontes.

Para alcançar esses objetivos e, ao mesmo tempo evitar uma mistura desordenada de informações, manterei aqui a ordem cronológica das expedições. No entanto, primeiramente é preciso repetir que os exploradores dos quais possuímos relatos de suas expedições oficiais não foram os primeiros e, excetuando Urbano e Labre, eles podem ser classificados como viajantes e ou funcionários públicos em exercício como Henrique de Matos e Wilkens de Mattos, pois não se estabeleceram no Purus. Antes, durante e posterior a essas expedições e relatos o Purus foi um lugar de atração para inúmeras pessoas que adentravam o rio em busca de suas riquezas. Por exemplo, com Chandless (1866a , p. 92) e com Coutinho (2009d [1863], p. 265, 273. 275), ficamos sabendo que o Purus já vinha sendo explorado periodicamente muito antes de sua estada na região pelos assim chamados regatões - comerciantes independentes que navegavam os rios vendendo e fazendo escambo com os indígenas. Segundo Chandless, oito anos antes de sua expedição iniciada em 1864 da qual participaram bolivianos e índios Paumari o Purus teria sofrido com epidemias o que teria feito com que muitos abandonassem suas colocações. Mesmo assim, quatro ou cinco homens teriam continuado a explorar o rio nos anos seguintes. Nesse mesmo sentido é que Serafim Salgado afirma que em 1852 um homem negro de nome Hygino residiria no Purus. Além do mais, Chandless $\left(1866^{\mathrm{a}}\right.$, p. 118) informa que, na época em que esteve no Purus, metade dos Paumari e oito a dez Apurinã entendiam a língua-geral o que indica um contato intensivo de longa data. De semelhante forma, em 1863, Coutinho afirma que os regatões conheciam muito bem os Paumari e os Juberi, denominados por eles de Purupurú em referência à moléstia de pele que os deixava com a epiderme cheia de pintas pretas e brancas. Coutinho também traz a informação de que os Apurinã trocavam crianças capturadas de outras aldeias com esses regatões e que o próprio Urbano mantinha feitorias no Purus nas quais utilizava mão de obra indígena, dentre essa mão de obra encontravam-se vários Apurinã (COUTINHO, 2009d [1863], p. 265, 270, 273). Dessa forma, podemos tomar como certa a hipótese de que as riquezas do Purus já eram exploradas e conhecidas muito tempo antes dos 
relatos em questão e que os povos indígenas mantinham contatos comerciais regulares prejudicados apenas em anos de epidemias.

Essa hipótese se torna mais verídica quando analisamos os relatos produzidos por Henrique de Matos e João Wilkens de Mattos. Em 1845, Henrique de Matos avalia que, na Província do Amazonas, nenhuma vila ou lugar teria deixado de sentir as consequências da Cabanagem (1835-1840), que todo o comércio e agricultura teria parado e que muitos lugares tinham sido abandonados (MATOS, 1979 [1845], p. 145). Tanto no Baixo Amazonas (Pará), onde os conflitos tiveram início, quanto no Alto Amazonas (Província do Amazonas), onde a "população" manteve-se "fiel" ao Império Central, houve uma enorme depopulação causada pelos conflitos e por epidemias. Em relação ao Purus, podemos tomar como fato que os surtos epidêmicos e os conflitos, além da diminuição física da população indígena, provocaram o afastamento da população indígena para o interior menos acessível. Os lugares mais distantes nas cabeceiras dos igarapés eram tidos como espaços de refúgio nos quais poderiam recuperar a saúde, pois assim estariam distantes dos focos de contaminação. Essa também é a argumentação de Aparecida Vilaça (2006, p. 418) sobre os Wari' na segunda metade do século XX quando afirma que, durante um surto, eles fugiam em pequenos grupos familiares para o interior da floresta passando longos períodos ou anos até que os sobreviventes recuperavam sua saúde e a necessidade de experienciar a alteridade os fazia procurar novamente seus parentes.

No relato de Henrique de Matos, também fica patente que tanto a administração portuguesa quanto a imperial direcionavam seus esforços para o controle do Rio Negro e do Rio Branco. Esses eram lugares nos quais a presença espanhola, francesa, holandesa e inglesa ameaçava as pretensões do domínio português sobre a região. Para o controle do Solimões, desde a segunda metade do século XVIII, existia o Forte de São Francisco Xavier de Tabatinga, na atual fronteira com o Peru e a Colômbia. Para o controle do Madeira, nas margens do Rio Guaporé, na fronteira com a Bolívia, também da segunda metade do século XVIII, existia o Real Forte Príncipe da Beira (MEIRELES, 1989). Assim, entre os fortes de Tabatinga e do Guaporé, havia um hiato da administração. Concentrando seus esforços ao Norte, os rios Purus e Juruá foram abandonados pela administração. Isso explicaria também porque, de uma região muito mais próxima como o Purus, existiria pouca documentação. No entanto, isso não significa que o Rio Purus não era conhecido ou explorado. O relato de Henrique de Matos, nesse sentido, demonstra que o rio era bastante conhecido e explorado para a extração de salsaparrilha, para a caça de peixeboi e de tartarugas e para a pesca de pirarucu já na primeira metade do século XIX. Na época da 
seca, também se fabricava muito "azeite dos ovos das tartarugas". Sobre a população, diz que "o Rio Purus é igualmente habitado de Nações Selvagens, com quem todavia se comercia, e das muitas as principais são Muras, Purus, Panauari, Cathanaxis, e outras de menor vulto (...)" (MATOS, 1979 [1845], p. 170).

Entretanto, o conhecimento de Henrique de Matos sobre o Purus ia além apontando para os campos naturais (resquícios de serrado) no Alto Purus (atualmente Médio Purus) que poderiam ser explorados para a criação de gado, para os rios conhecidos e para outros povos já em constante contato. Quando as primeiras fontes se referem ao Alto Purus, estão, na verdade fazendo referência ao que hoje chamamos de Médio Purus. Atualmente, o Baixo Purus corresponderia à região que vai da foz do rio até as imediações do município de Lábrea, o Médio Purus corresponderia à região que vai daí até a fronteira do estado do Acre e o Alto Purus corresponderia à região do Acre.

Henrique de Matos vai falar do Rio Tapauá no qual se poderiam encontrar muitos povos, dos quais “os Cathanaxis já domesticados”, mas também os Cathuquenes, Mamory e Chinaniri ainda bravios. "Depois deste rio segue um Purunumere (rio pequeno e estreito), denominado Mereunim, e neste habita a Nação Puincanary, bastante populosa. Nos Rios Ituxi, Auicimá e Ciriuny, também habitam os mesmos Cathanaxis, e no Rio Vacimá, os Indígenas Caminará" (MATOS, 1979 [1845], p. 171). Alguns desses rios conservam seus nomes ainda hoje, embora o mesmo não possa ser afirmado dos grupos indígenas que nomeia. Os tais Chinaniri, Puincanary e Cathanaxis, pela aproximação linguística, pela importância dada pelo relato e pela localização, poderiam ser, na verdade, os atuais Apurinã. Puincanary é inclusive o nome mais próximo à atual autodenominação dos Apurinã que encontrei nos relatos. Ao transliterar o etnônimo, as semelhanças podem ser observadas: Puĩkanary, enquanto a atualmente autodenominação é Pupỹkary. Chinaniri, por sua vez, parece estar fazendo referência ao grupo familiar Ximakury (família do peixe) e poderia ser traduzido "o povo do peixe", uma vez que niri (niry ou nyry) corresponde à filiação paterna na língua apurinã.

Uma pergunta, no entanto, ainda ecoa dessa fonte, como poderia um administrador que atuou mais diretamente com o Alto Rio Branco saber tanto sobre o Purus? É o próprio Henrique de Matos quem nos dá a resposta.

Importantíssimo serviços tem prestado no mencionado Rio Purus o cidadão Manuel Urbano da Encarnação, que viajando-o todos os anos a extração das drogas do País, tem arrancado das florestas quatorze Nações de Indígenas para 
a margem do rio, fazendo-os povoar, e trabalhar em roças de mandioca, e outras plantações (...) (MATOS, 1979 [1845], p. 171).

Portanto, a fonte principal de Henrique de Matos é Manoel Urbano que já explorava há bastante tempo o Rio Purus. Os quatorze povos seriam: Ciacu, Arapá, Ciuni, Aporiná, Canamaré, Iamamadi, Cauaruná, Puiaguari, Amarunan, Ciriuni, Vanarri, Muriná, Terroan, Mangue e Iacuritim. Nem todos esses nomes devem ser compreendidos como se designassem povos distintos, pois um mesmo povo pode estar aqui sendo nomeado diferente. Esse é o caso de alguns etnônimos que claramente fazem referência ao lugar e não ao nome do povo, como, por exemplo, Terroan (Teruã) e Ciriuni (Seruini). Além dos Kanamari (Canamaré) e dos Jamamadi (Iamamadi), aparece também, pela primeira vez, o nome Apurinã (Aporiná). Sobre os Kanamari, Henrique de Matos (1979 [1845], p. 171) afirma ainda que, segundo Urbano, eles possuiriam roupas, ferramentas e moedas espanholas que utilizavam ao redor do pescoço como ornamento.

A admiração e o reconhecimento de Henrique de Matos pelo papel exercido por Urbano na ocupação do Purus o faz requerer ao governo provincial que lhe conceda o título de Capitão. Mas suas intenções iam além do mero reconhecimento, pois, como podemos depreender de suas palavras, ao apoiar um explorador que já mantinha relações pacíficas com vários povos indígenas do Purus, o Estado poderia estabelecer um controle mais efetivo e evitar possíveis conflitos. Diz ele:

Os serviços prestados pelo dito Urbano da Encarnação merecem toda a devida consideração do $\operatorname{Exm}^{\circ}$ Governo para que o nomeie Principal das Nações por ele catequizadas no mencionado Rio Purus com a referida nomeação de Capitão, não só porque prestará mais grato ao serviço da nação, e do Estado, como porque goza de grande influência, e amizade naquelas Nações que o respeitam, e o servem; ficando por esta forma isento do serviço das Armas com que o perseguem, e o embaraçam a viajar ao dito rio. (MATOS, 1979 [1845], p. 172).

O relato de Wilkens de Mattos (1856), por sua vez, além dos etnônimos que registra para o Purus, também traz informações sobre uma missão fundada no Baixo Purus em 1853 num lugar denominado Jury. Segundo Mattos, os principais povos do Purus seriam os Muras, os Caunicis, os Mamarûs, os Catequinas, os Sipés, os Intanás, os Turunhas, os Coracatis, os Caripunas, os Jamamadis, os Apolinas e os Turupurús. Os novos etnônimos indicam que as fontes de Mattos eram diferentes das de Henrique de Matos, mas ele não deixa entrever quais. Provavelmente tratava-se de conhecimento presente no senso comum entre os comerciantes da Barra do Rio Negro (Manaus). No entanto, além dos Purú-purú, dos Mura, dos Jamamadi ele 
também registra os Apurinã que aparecem sob o nome Apolina, registrado pela segunda vez. Em relação à missão, diz que o frei Pedro de Ceriana teria sido transferido pela resolução de 7 de janeiro de 1853 da missão do Andirá para a missão São Luiz Gonzaga no Purus. A missão do Andirá teria sido transformada em uma freguesia e provida de um pároco regular, por isso não necessitaria mais dos serviços do missionário. Gunter Kroemer (1985, p. 51), por sua vez, afirma que o frei Pedro de Ceriana - italiano de nome Pier Paolo Crespi da Ceriana -, após sua nomeação, teria se mudado para o Purus em julho de 1854. A missão teria sido fundada no lago Uamurá e fechada em 1856 devido às "calúnias dirigidas contra o frei por parte de regatões e comerciantes". Tudo indica que o missionário entrou em disputa com os particulares pelo controle da mão de obra indígena.

A missão do Purus, assim como a expedição de Serafim Salgado em 1852, pode ser entendida como um esforço da administração do governo provincial em estabelecer um domínio mais regular sobre a região. No entanto, Mattos (1856, p. 128) defende em seu relato a necessidade de mudar a missão para o Médio Purus, para a região compreendida entre os rios Tapauá e Pauini, pois o local onde estava estabelecida seria "mais própria para operações comerciais" do que para os "encargos da catechese, não offerecendo aquellas vantagens que seriam para desejar-se”. No Baixo Purus, a missão estaria atuando com os Mura, os quais já seriam todos batizados, falantes do português e engajados em atividades extrativistas e comerciais. Portanto, em sua visão, não necessitariam do trabalho de um missionário. $\mathrm{O}$ missionário deveria envidar seus esforços para atrair povos que ainda representavam alguma resistência ao projeto colonizador, o que era traduzido como "aqueles que necessitavam de catequese".

Adentremos agora nas expedições propriamente ditas que tiveram lugar a partir da segunda metade do século XIX. Nessas expedições, a primeira coisa que chama a atenção é o uso do trabalho dos índios. Como lembra Kaori Kodama (2009, p. 38), os índios eram importantes para mapear as regiões, para nomear rios e povos indígenas "onde não havia o mapeamento bem elaborado". Mas eles também faziam o trabalho braçal. Nesse sentido, a expedição de Serafim Salgado de 1852, por exemplo, com a deserção dos Mura que estavam empregados como remeiros, só pôde prosseguir viagem porque obteve ajuda dos Purú-purú, dos quais nomeia o cacique Mamurité e o índio Baidá que teriam descido com ele até Manaus em busca de pagamento pela ajuda prestada. Sua única menção sobre os Apurinã, como já descrevi acima, seria que eles perseguiriam os Cucamas. No entanto, o que chama mais a 
atenção no relato de Salgado (1853) é que ele cruza todo o território dos Apurinã, tanto na subida quanto na descida, e não registra nenhum contato, nenhum imprevisto ou conflito. Ao contrário, afirma que a viagem foi realizada sem nenhum contratempo.

Na expedição do vapor Pirajá em 1862, da qual Coutinho (2009b [1862], p. 183) tomou parte, participaram também alguns Paumari, Catauixi e Apurinã que Urbano levava junto com ele. O principal trabalho deles era o corte de lenha para o vapor, mas também davam informações sobre os lagos, sobre os igarapés e sobre os demais povos indígenas. Essa expedição produziu, entre outros, dois importantes documentos históricos de autoria de Coutinho. O primeiro (2009a [1863], p. 203-243) é uma relação de pontos geográficos como lagos, barreiras (corredeiras), feitorias dos moradores, rochedos e informações sobre povos e lideranças indígenas. O segundo (2009d [1863], p. 253-299) traça representações e informações sobre os povos indígenas em forma de um relato. Como o ponto mais ao sul atingido pela expedição foi Hyutanahã, toda informação além desse ponto deve ser creditada exclusivamente aos conhecimentos de Urbano. Especificamente sobre os Apurinã, Coutinho afirma: "são bonitos, simpáticos e vigorosos, (...) distinguem-se ainda pelo amor ao combate e beleza dos seus ornatos de pena" (2009d [1863], p. 273).

Na relação, Coutinho afirma que, nas barreiras de Quiciá, existiria uma maloca apurinã dirigida pelo tuxaua Cauacanari (Kawakanary). Esse cacique teria estado algum tempo em companhia de Urbano e é qualificado como "dócil e inteligente". No Rio Acimã, teriam duas malocas apurinã e, no Rio Tumiã, mais seis. Pouco acima da foz do Igarapé Mamoriá, Urbano afirma que existiriam três malocas apurinã e mais acima os Jamamadi. Nos lagos Mataripuá e Inari, também existiam malocas apurinã. Já no Seruini, um dia de caminhada a montante desde a foz, num afluente da margem direita, Urbano diz que existiam duas malocas apurinã. Esses índios hostilizariam outros Apurinã que se localizariam rio acima. "É uma perseguição constante e feroz, do que têm resultado muitas mortes" (COUTINHO, 2009a [1863], p. 239). Nas barreiras de Jamerheari, existiriam dois caminhos, um que levava a uma aldeia Apurinã no Teruã e o outro a uma aldeia Jamamadi. Essa barreira parece ser as corredeiras que se encontram logo abaixo do atual centro urbano de Pauini. Já, no Rio Pauini, existiriam seis malocas Apurinã distantes até nove dias de viagem rio acima. No igarapé Seuini, provavelmente o atual Canacuri acima do Rio Pauini (conforme mapa de CHANDLESS, 1866a), também existia uma maloca apurinã e uma jamamadi mais a montante. E assim vão se sucedendo outras aldeias nas barreiras de Cachapá, de Jamoenham e de Camareté. No 
Igarapé Anori, segundo Urbano, existiriam muitas aldeias apurinã. No Rio Inauiní, havia duas malocas apurinã e outras jamamadis a montante. Logo acima do Igarapé Anori havia um caminho que levava até as malocas da cabeceira do Tacaquiri. Também nas barreiras do Aquiri (Acre), na margem esquerda do Purus onde hoje é a atual aldeia Camicuã, encontravase uma aldeia Apurinã. No Rio Acre, Urbano, diz ter encontrado alguns índios ao subir o rio durante 20 dias, mas não compreendeu a sua língua. Diz que usavam machado de pedra que adquiriam de outra tribo da margem esquerda. Provavelmente dos Manchineri. Acima da boca do Rio Acre, Urbano também diz ter encontrado algumas aldeias, como na barreira de Putucuham onde existiria uma aldeia mista apurinã-kanamari. "É o ponto de contato destas duas tribos. Vivem congregadas pelo matrimônio, e tanto que é difícil distingui-las presentemente" (COUTINHO, 2009a [1863], p. 241).

Além dessas aldeias, Urbano também encontrou uma aldeia apurinã no Punicici, um afluente do Rio Ituxi (COUTINHO, 1866 [1865], p. 127) e outra no Rio Paciá. Segundo ele, os Catauixi do igarapé Mari seriam “perseguidos pelos Ipurinás do Rio Paciá, que têm a sua frente o Tuxaua Macutê, um dos mais afamados guerreiros do Purus". Macutê (Makuty) reuniria 400 guerreiros em arco e aterrorizaria os Catauixis (COUTINHO, 2009b [1862], p. 197). Acima da foz do Sepatini, uma aldeia apurinã estaria confederada com os Paumari para se defenderem de uma tribo guerreira denominada Quarunás. Os Quarunás falariam a mesma língua dos Apurinã, mas, conforme informações de Urbano que Coutinho registrou, estariam com as relações cortadas (2009b [1862], p. 198; 2009d [1863], p. 275). Coutinho também observa que, segundo Urbano, a guerra seria "um elemento de vida para os Ipurinás, e o contrário acontece com os Catauixis, pacíficos lavradores, amigos da tranquilidade" (2009b [1862], p. 196). Coutinho inclusive registra a opinião de Urbano de que a guerra seria “o exercício predileto" dos Apurinã e eles possuiriam mesmo uma "ideia de federação", pois conseguiriam reunir várias aldeias para combater coletivamente (2009d [1863], p. 273). Assim os Apurinã são apresentados como um grupo numeroso e perigoso em relação aos demais povos do Purus. No entanto, o mesmo Coutinho, em um ofício ao presidente da Província em 1862 apresentando os resultados da expedição do vapor Pirajá, também afirma que

As numerosas tribos Maneloneris e Canamari possuem os melhores predicados para que de sua aquisição venha a colher o país um grande resultado. Os Jamamadis, Ipurinás e Catauixis, lavradores por excelência, só esperam uma inteligência guiada pelo patriotismo para enriquecer $o$ Amazonas (COUTINHO, 2009c [1862], p. 248). 
Nesse relato, os Apurinã aparecem como agricultores esperando que "uma inteligência guiada pelo patriotismo" os conduza. E essa inteligência seria Manoel Urbano, pois dentre os objetivos do ofício estava o de indicar Urbano como Diretor de Índios do Purus. A posição de Coutinho, portanto, era de que "o índio é bom, dócil, e propenso a civilização". Se respondiam com violência, isso advinha das perseguições que sofreram durante três séculos. Para ele, o comportamento dos "civilizados" tinha sido pior. Portanto, defende que o Estado teria o dever de educar os indígenas, pois "o índio é uma criança, nem mais, nem menos; deixá-lo, pois, entregue às leis da natureza é uma verdadeira barbaridade. Criança vai para onde lhe guia o instinto, sem a consciência do mal ou do bem, sem responsabilidade consequentemente" (COUTINHO, 2009d [1863], p. 279). De sua condição infantil, portanto, é que adviriam os conflitos internos dos Apurinã. Incapazes de agenciarem sua própria história, na visão de Coutinho, eles necessitariam da mão protetora do Estado que os salvaria de um destino inevitável: reduzidos por seus conflitos internos e aniquilados pelo contato violento com a sociedade não-indígena.

Como nas expedições anteriores, na expedição de Chandless entre 1864 e 1865, também tomaram parte diversos indígenas, dentre eles alguns Apurinã, e o prático Manoel Urbano. A importância da comunicação com os Apurinã durante a viagem pode ser ilustrada pelo registro de Chandless quando afirma ter ficado mais de duas semanas em Conotama - uma colocação de Urbano logo acima da boca do Rio Mucuim - esperando pelo filho de Urbano que o acompanharia na viagem, de nome Manoel Braz Urbano Gil da Encarnação. A ajuda do filho de Urbano seria indispensável, pois era fluente em apurinã (CHANDLESS, 1866a , p. 94). Mas também alguns Apurinã, como já descrevi acima, devido ao contato constante com mercadores e exploradores de borracha, já dominavam o português. Nesse sentido, no mapa de Chandless (figura 3), entre os atuais municípios de Boca do Acre e Pauini, aparece uma indicação de uma maloca apurinã cujo chefe falaria português. 
Figura 3: Recorte da região de Boca do Acre do mapa de Chandless de 1866

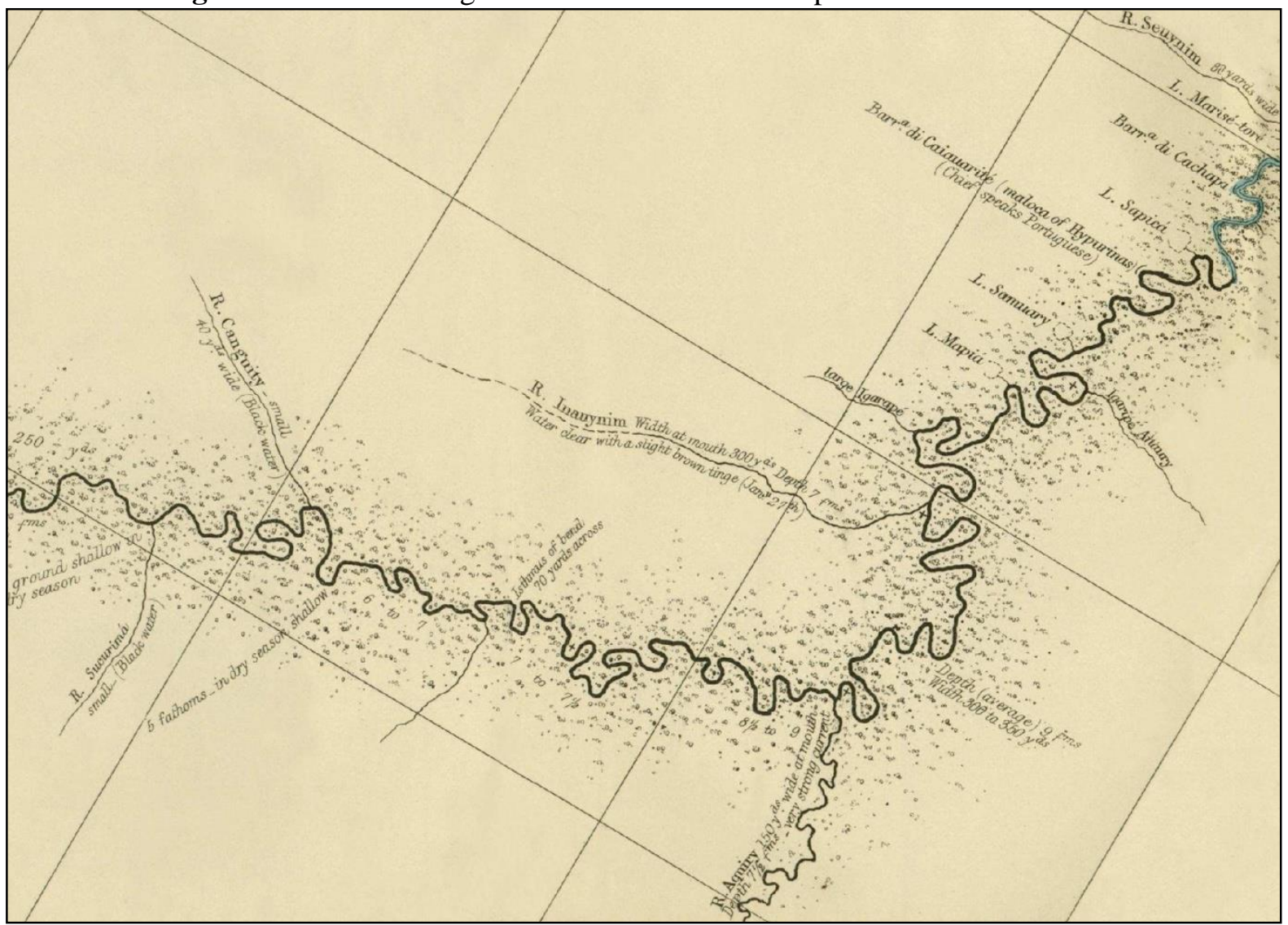

Fonte: CHANDLESS, 1866a

Sobre o território apurinã, Chandless $\left(1866^{\mathrm{a}}\right.$, p. 97) diz que os Apurinã viviam nas margens do Rio Purus e seus tributários. Enquanto na margem esquerda, em direção ao Rio Juruá, podiam ser encontrados os Jamamadi (figura 4), na margem direita, em direção ao Madeira, não haveria notícias de outros grupos além dos Apurinã. Em detrimento da localização dada por Coutinho e Urbano que observam a presença dos Apurinã já no Rio Paciá (2009d [1863], p. 273), uma frase de Chandless em especial que trata da delimitação do território tem sido replicada em vários trabalhos posteriores como a primeira tentativa de delimitação do território apurinã (LAZARIN, 1981, p. 11). Diz ele: “Acima do Rio Sepatini e daí até o Rio Iaco, uma distância ao longo do rio (omitindo as curvas) de cerca de 300 milhas, estende-se as tribos dos Apurinã, a mais numerosa, guerreira, e formidável no Purus" (CHANDLESS, 1866 p. 96) ${ }^{4}$. Nessa sentença, além do extenso território, ecoa também a representação guerreira. E Chandless continua: "Os Apurinã parecem deleitar-se na guerra, e estar constantemente

\footnotetext{
4 "Above the River Sepatinim and from this to the River Hyacu', a distance along the river (omitting the bends) of nearly 300 miles, extends the tribes of Hypurinás, the most numerous, warlike, and formidable on the Purûs”.
}

Fronteiras: Revista de História | Dourados, MS | v. 19 | n. 33 |p. 11 - 42 | Jul. / Dez. 2017 
engajados nela (principalmente com os de sua própria tribo), com ou sem justa causa frequentemente, de fato, demandando um desafio" (CHANDLESS, 1866ª p. 96) 5 .

Figura 4: Recorte da região de Pauini do mapa de Chandless de 1866

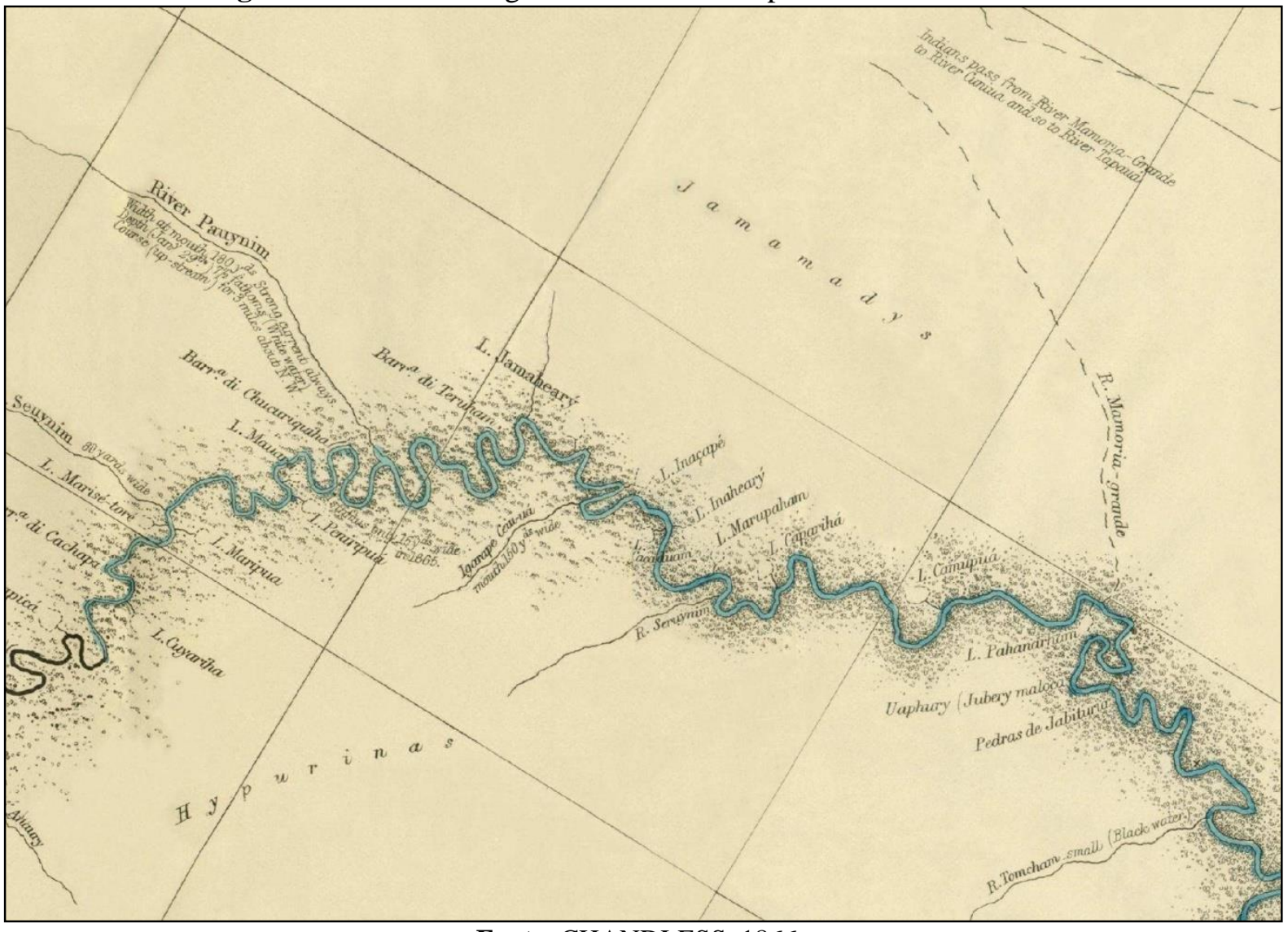

Fonte: CHANDLESS, 1866a

Como prova da conflituosidade, Chandless $\left(1866^{\mathrm{a}}\right.$, p. 96) diz que teria visto muitos Apurinã com ferimentos provocados por flechas. Embora afirme sua condição guerreira, também observa que, durante suas expedições, eles nunca foram molestados pelos Apurinã, mesmo que eles sempre se apresentavam bem armados. E conclui: "Eu gosto dos Apurinã, porque eles são bem educados e têm um certo ar de auto-respeito" (CHANDLESS, 1866a , p. 97) ${ }^{6}$. A experiência com os Manchineri também serviu para delimitar o caráter dos Apurinã. Segundo Chandless, "ao contrário dos Apurinã, eles não agarraram seus arcos, mas vieram ansiosamente até nós com tabaco, bolas de algodão, fios etc., pedindo por facas, anzóis etc.”

5 "The Hypurinás seem to delight in war, and to be constantly engaged in it (chiefly on those of their own tribe), with or without cause - frequently, indeed, sending a challenge".

6 "I like the Hypuriná, for they are well-mannered, and have a certain air of self-respect about them". 
(CHANDLESS, $1866^{\mathrm{a}}$, p. 101)7 . Os Manchineri, nesse sentido, foram tomados como mais dados ao comércio enquanto os Apurinã à guerra. Como prova de sua inclinação para o comércio, os Manchineri inclusive dominariam algumas palavras em espanhol como muchacho, muchacha, cuchero, cuchillo e saberiam diferenciar o valor de um machado português de um machado estadunidense. Mais do que isso, os Manchineri só não manteriam uma relação mais intensa de comércio com os brasileiros porque estariam evitando descer o Purus com medo dos Apurinã. Nesse sentido, Chandless diz que os próprios Apurinã teriam contado que atacaram duas canoas Manchineri em 1863 que estavam descendo o Purus para comerciar. Todos os ocupantes teriam sido mortos (CHANDLESS, 1866 ${ }^{\mathrm{a}}$, p. 101).

Na fronteira sul do território apurinã, Chandless (1866a: 100) registra um suposto povo denominado Uainamary, com quem a expedição de Serafim Salgado teria entrado em atrito e disparado contra eles e que depois disso teriam se retirado para o interior e não mais sido vistos. Parece, na verdade, tratar-se de um grupo Apurinã, pois o etnônimo corresponde ao substantivo sucuri na língua apurinã (wainamary) e, como apresentarei mais adiante, a interpretação desse suposto povo como um grupo Apurinã pode ser corroborada com outras pistas advindas da cultura apurinã. Seja como for, a descrição de um suposto povo denominado Uainamary ecoaria nos relatos etnográficos posteriores.

Os Kanamari, por sua vez, são descritos como agricultores pacíficos que seriam amigos dos Apurinã e viveriam trocando casamentos com eles (CHANDLESS, 1866 a p. 100). Mas Chandless (1866 a p. 105) também afirma que os Kanamari e os Manchineri se compreendiam; o que também indica trocas comerciais e matrimoniais. A troca de casamentos permitia que alguns indivíduos de cada povo dominasse a língua do outro grupo o que facilitava na hora das trocas comerciais. Mas as trocas também podem ser observadas nos empréstimos linguísticos como, por exemplo, o nome do Rio Purus nas línguas indígenas. Os Paumari o chamariam Wainý, os Apurinã o chamariam Wéni (Wene), e os Manchineri o chamariam Weni. Os três nomes são, portanto, claros correlatos, o que demonstra as relações entre os diferentes grupos (CHANDLESS, $1866^{\mathrm{a}}$, p. 118). O próprio etnônimo Manchineri (Manetenery na grafia de Chandless) também parece provir da língua Apurinã ou tem seu correlato em Apurinã, já que os Manchineri estão linguisticamente mais próximos dos Apurinã do que qualquer outro povo da família Aruak (FACUNDES, 2002, p. 90). Etimologicamente, em apurinã, a palavra significa

\footnotetext{
7 "Unlike the Hypurinás, they did not seize their bows, but came eagerly to us with tobacco, balls of cotton, thread, \&c., asking for knives, fishing-hooks, \&c.”.
} 
"povo do veado" (maniti = veado-mateiro; niry = pai, parente). Além disso, em uma nota, Chandless (1866b, p. 123) afirma explicitamente que o nome teria sido dado pelos Apurinã em referência ao poncho tingido de urucum que eles usavam.

Sobre a presença dos Apurinã no Rio Acre, Chandless (1866b, p. 119) diz que eles habitariam suas margens até cerca de dez jornadas rio acima. Também observa que eles viajariam três dias e meio em direção leste até um rio menor que o Rio Acre para adquirirem implementos de pedra. Chandless acreditava tratar-se do Ituxi. Depois dos Apurinã, estariam os Capéchenes, mas Chandless não conseguiu vê-los. Essa informação ele obteve de Urbano que, em sua viagem, teria encontrado com esse povo. Afora essas referências, não existe na literatura um grupo com esse nome. Provavelmente, tratava-se de um subgrupo de outro povo que fora nomeado como um povo próprio devido às variações linguísticas e culturais e, mais provavelmente ainda, pela pouca informação que Urbano conseguiu coletar sobre eles em seu curto encontro. Os supostos Capéchenes, nesse sentido, poderiam ser inclusive um grupo Apurinã, uma vez que pode ser tomado como uma realidade empírica que toda a extensão do atual Rio Acre no que hoje faz parte do estado do Acre era território tradicional Apurinã. Nesse sentido, o Rio Xapuri e o atual município de Xapuri, no Acre, fazem referência a um povo que habitaria a região e que fora conhecido com este nome. Na verdade, o nome parece estar fazendo referência a um dos clãs apurinã, a saber, Xuapurinyry ${ }^{8}$.

Nesse mesmo sentido, ainda no Rio Acre, Chandless (1866b, p. 121) encontrou um grupo indígena sobre o qual afirma que sempre repetiam os nomes dos substantivos com o sufixo "rá" quando perguntados para pronunciarem novamente; como no caso da palavra rio "washiri", repetida ficaria washiri-rá. Isso pode ser um indicativo de que tal povo poderia ser, na verdade um grupo Apurinã ou relativo à família Aruak, porque em apurinã o sufixo - ra é usado para dar ênfase ou reafirmar algo, de modo que a palavra poderia ser traduzida "é washiri". Além do mais, o substantivo empregado para o rio parece ser correlato da palavra apurinã para designar o Rio Acre, a saber, Akyry ou Wakyry. O nome do Rio Acre, que futuramente daria nome ao estado do Acre, é referenciado por diversas fontes - o que pode ser verificado mais abaixo - como sendo procedente da língua apurinã

\footnotetext{
${ }^{8} \mathrm{O}$ povo Apurinã divide-se em dois troncos/clãs exogâmicos patrilineares: Xuapurinyry e Miutymãnety. O casamento correto ocorre entre esses dois clãs. Aqueles que pertencem ao mesmo grupo são chamados de nepyry ou nepyru (meu irmãosã, minha irmã) e aqueles que pertencem ao outro clã de numinapary ou numinaparu (meu cunhado, minha cunhada).
}

Fronteiras: Revista de História | Dourados, MS | v. 19 | n. 33 | p. 11 - 42 | Jul. / Dez. 2017 
e, em 1958, essa informação é também replicada por Castelo Branco (1958, p. 4) em seu ensaio histórico "Acreania".

Esse grupo indígena com o qual Chandless entrou em contato também possuiria ainda alguns artigos de ferro que seriam de uma marca comercializada no Pará (CHANDLESS, $1866 b$, p. 122). Isso demonstra que esse grupo estaria comercializando com outros grupos rio abaixo ou através de comércio com o Rio Madeira. Uma das tribos que Chandless contatou mantinha comércio regular com os Manchineri, pois tinham ferramentas de ferro, utilizavam anzóis, conheciam o sal e um dos chefes usava um poncho. Além disso, Chandless (1866b, p. $123 ; 120)$ ainda observa que todos os índios do Rio Acre tinham também cachorro e que o tabaco nativo seria abundante na região. A presença de tabaco nas praias do Rio Acre também foi observada por Urbano (COUTINHO, 2009a [1863], p. 241). Provavelmente, a abundância da planta advinha do manejo dos indígenas, pois o rapé é muito consumido pelos Apurinã e outros povos da Amazônia Ocidental. Além da inalação de rapé, Chandless (1866 a p. 98) também confirma que os Apurinã mascavam coca. Portanto, se esses dados não são suficientes para afirmar que esses grupos eram parentes dos Apurinã, pelo menos são prova das intensas trocas comerciais e matrimoniais entre os diferentes grupos indígenas da região e com os nãoindígenas tanto dos lados boliviano e peruano quanto do lado brasileiro.

Sobre os aspectos culturais, Chandless não faz grandes observações sobre os Apurinã. Isso ocorre porque ele não teria passado tempo suficiente em uma aldeia para fazer tais observações. Assim, limita-se a reproduzir uma informação que provavelmente obteve de Urbano acerca do tratamento que os Apurinã dispensariam aos seus mortos. Diz ele:

Os Apurinã, depois de um tempo, quando os ossos estão limpos, os desenterram, e fazem um festival e uma oração fúnebre; $\mathrm{O}$ orador toma, por exemplo o osso do braço, e dizendo, "com este braço ele fez", etc. - reconta os grandes feitos do morto, depois disso eles guardam os ossos cuidadosamente (CHANDLESS, $1866^{\text {a }}$, p. 97) ${ }^{9}$.

Essa mesma informação pode ser encontrada no único documento de autoria do próprio Manoel Urbano datado de 1882. Embora seu documento fale de um índio mais genérico, misturando por vezes informações sobre os Paumari, sobre os Jamamadi e sobre os Apurinã, é possível extrair e separar algumas informações a respeito dos Apurinã, como quando registra

\footnotetext{
9 "The Hypuriná, after a while, when the bones are clean, take them up, and have a festival and a funeral oration; the orator taking up, e. g. the arm-bone, and saying, 'with this arm he did', \&c. - recounting the great deeds of the dead; after this they guard the bones carefully".
} 
os nomes Mendy, Joimatê ou Carimandê para falar do "maioral de sua religião". Os dois últimos nomes são claramente nomes Paumari e Jamamadi; enquanto que Mendy (Mẽety) é o substantivo empregado em Apurinã para designar o xamã. No que diz respeito à cerimônia fúnebre, provavelmente Urbano registra-a alguns anos mais tarde por a ter repetido inúmeras vezes para os outros exploradores interessados em dados etnográficos. Diz ele a respeito dos "selvagens" (os quais podemos entender tratar-se dos Apurinã):

[...] pegam na cana dos braços dos homens mais notáveis, já fallecidos, que houve entre elles, e salta um dos chefes no meio do salão fazendo todos os gestos d'essa pessôa quando viva, dizendo: - Este foi quem venceu tal guerra! - Este foi quem nos ensinou a fazer tal couza! E tudo quanto fazia quando vivo. Acabado isto entra outro dizendo da mesma forma o que fazia o falecido. Este festejo só é feito aos homens mais notáveis que houve entre eles. Depois de acabada a festa, guardavam os ossos dentro d'um panelão dependurado" (URBANO DA ENCARNAÇÃO, 1902, p. 96).

Muito mais do que um culto aos antepassados, parece que estamos diante de uma estratégia de memorização histórica. Guardar os restos mortais e utilizá-los em cerimônias nas quais são relembrados acontecimentos históricos comprova que a sociedade apurinã mantinha uma identidade histórica, o que também ajuda a explicar a unidade apesar da grande dispersão e das diferenças linguísticas ou mesmo dos conflitos internos. Mas, ao frisar que essas cerimônias parecem ter sido reservadas aos "homens mais notáveis", Urbano também nos dá pistas para pensarmos que essa sociedade não desconhecia a hierarquia social.

Mesmo tendo relativizado e colocado o "relato de notícias sobre o Purus" do Coronel Labre (1872) como um escrito de segunda mão - portanto de menor importância como fonte sobre os índios do Purus -, é importante apontar as representações que tece acerca dos Apurinã, pois ele é um dos principais colonizadores. Suas observações podem ajudar a compreender como os colonizadores imaginavam e construíam suas relações com os indígenas. Para informações geográficas e etnográficas mais científicas, em seu livro-panfleto, Labre remete aos escritos de Chandless, pois seu escrito é "destinado ao povo", para aquelas pessoas que pretendem se estabelecer no Purus, de preferência em sua recém-criada colônia. Em seu intento de fazer propaganda, Labre parece dividir-se entre a generalização e a especificação de informações sobre os indígenas do Purus; como quando diz que a poligamia seria um direito do chefe, que os indígenas costumam retribuir a dádiva com dádiva; que oferecem suas mulheres para os estrangeiros, quando relativiza o poder do chefe ou mesmo quando afirma que os indígenas seriam pacíficos apesar de sua maledicência e desconfiança (LABRE, 1872, p. 16). 
Assim, ao mesmo tempo em que desqualifica os indígenas, os transforma em objetos de curiosidade e desejo. Nesse sentido, a imagem do Éden é evocada como uma forma de atração pela abundância e pelo desejo carnal.

Este paiz é sem duvida um novo mundo, onde se acha a raça do pae Adão por aqui dispersa, e ainda com os mesmo habitos e costumes do velho papá, pois ainda não foram expulsos do seu paraiso; não conhecerão ainda a nudez, em que vivem; o seu edem é bem fornecido de frutos e animaes, por isso não têm necessidade do trabalho e do invento (LABRE, 1872, p. 14).

O trabalho da Igreja (1872, p. 15) e do Estado é evocado para cristianizar e civilizar os indígenas. A Igreja, ao se estabelecer, garantiria o sucesso do projeto colonizador de Labre e o Estado ou poderia legalizar a exploração da mão de obra ou limpar a área para que as terras pudessem ser ocupadas. É assim que Labre, evocando a representação negativa da antropofagia, apresenta sua proposta.

Este nefasto costume é que os conserva na maldade, selvageria, e embrutecimento; convinha pois que o governo envidasse todos os esforços para arranca-los desta degradação, colonizando-os. Poderiam prestar valiosos serviços à lavoura, e serem cedidos a particulares, que os quizessem por contractos, mediante algumas vantagens. Para o bom resultado seria mui conveniente transporta-los insensivelmente para centros colonizadores, em outras províncias; no fim de três gerações estariam os seus descendentes civilizados, na lavoura, e o Estado teria homens úteis e aproveitáveis (LABRE, 1872, p. 25).

Dessa forma, disputando as terras e a mão de obra dos indígenas, Labre constrói sua proposta quase que desconstruindo o ideal paternalista de Silva Coutinho, pois se sobressaem os elementos negativos. Ou, como também observou Juliana Schiel (1999, p. 36): “a perversidade, no discurso de Labre, parece equivaler ao que, para Silva Coutinho, era ignorância, mas em ambos os casos eram defeitos que podiam ser curados. No caso de Labre, entretanto, o trabalho servil seria, mais do que um método de civilização, um fim em si mesmo”. No entanto, se Labre prima por abordar genericamente os indígenas vinculando os dados que oferece com seu projeto colonizador, também reproduz algumas informações mais específicas das quais podemos observar os interesses e estratégias próprias dos indígenas. Ele nos traz a informação de que muitos indígenas estariam envolvidos com o corte de seringa, com a coleta de salsaparrilha, de óleos vegetais e animais, de cacau e demais produtos. Em troca, eles requisitariam ferramentas, anzóis, ponta de flechas, cachaça e miçangas. Labre também 
reafirma que os indígenas usariam roupa na presença dos não-indígenas (1872, p. 22). Apesar de também ser de segunda e terceira mão, sua observação sobre o rito funerário Apurinã é mais detalhada que as outras versões, ao mesmo tempo em que afirma que os Apurinã praticariam o endocanibalismo.

\begin{abstract}
Alguns destes selvagens (Ipurinãs do Sipatiny) comem o pai, mãe e outros parentes, quando morrem; separam dos ossos toda carne, que comem, e juntos os ossos enterram com as práticas e horas devidas. Em geral, depois de dois ou mais annos costumão exhumar os corpor dos pais ou mães; tirada a caveira, cobrem de novo a sepultura. A caveira é lavada, seccada, e pintada de urucu, ou outra tinta vermelha; fazem-lhe à noite, durante uma semana, horas fúnebres com adorações; dançando levantam cantorias tristes em roda ou presença do objecto adorado, fazendo despedidas, e, findas estas praticas, enterram de novo em outro lugar a caveira, cumpridas as práticas funerárias do costume; e, feita esta última despedida, nunca mais revolvem o depósito do morto (LABRE, 1872, p. 21).
\end{abstract}

Ao final de seu livro-panfleto, Labre traz uma relação dos povos indígenas do Purus juntamente com algumas informações acerca de cada grupo. Sobre os Paumari, diz que antigamente habitariam o Baixo Purus, que falam o português e a língua geral e que sofreriam com problema de pele. Sobre os Juberi, diz que possuiriam os mesmo hábitos e costumes dos Paumari e que também sofreriam com as pintas na pele, mas que sua língua seria um pouco diferente. Sobre os Jamamadi, limita-se a dizer que evitariam o contato (1872, p. 27). Atenção especial é dispensada aos Apurinã, pois eram os mais numerosos e poderiam representar problema para o projeto de Labre.

Habitam desde o médio até o alto Purús, são mui numerosos, e de índole perversa, e máos instintos; são verdadeiros antropóphagos; entregam-se exclusivamente aos negócios e práticas da guerra, pilhagem e assassinato. Vivem em differentes tribus espalhadas em grande extenção do Purús, e seus afluentes (...). Apesar da sua malvadez não atacam a gente civilizada, a quem procuram fallar; matam porém traiçoeiramente para roubar, e comer os mortos. Fazem muito pouco commercio em troca de salsa, seringa, e óleo, que já vão aprendendo a colher com a gente civilizada (LABRE, 1872, p. 29).

Ao mesmo tempo em que Labre os descreve como maus e antropófagos que se entregariam "exclusivamente" à pilhagem, ao assassinato e à guerra, ele também reconhece que eles não atacam "a gente civilizada", isto é, os não-indígenas. Mesmo assim a ambiguidade continua, pois matam traiçoeiramente, fazem comércio e convivem e aprendem com os nãoindígenas. A ambiguidade pode estar fazendo referência aos Apurinã, mas também deve ser lida como uma exigência do próprio projeto colonialista de Labre. Ele não pode assustar seus 
pretendentes a colonos, mas também não pode se dar ao luxo de minimizar o que uma possível resistência indígena poderia significar para seu projeto. Assim, ele pretende tanto atrair a atenção e o interesse de particulares, quanto da Igreja e do Estado. Os particulares seriam os possíveis imigrantes nordestinos; a Igreja seu aliado no estabelecimento de estruturas permanentes; e o Estado seu principal parceiro do qual conseguiria concessões especiais como o usufruto da terra e da mão de obra indígena. Por exemplo, em 1888, Labre inclusive conseguiu, através do decreto $\mathrm{N}^{\mathrm{o}} 10.027-\mathrm{B}$, de 21 de agosto, a concessão para abrir e explorar uma estrada ligando sua colônia ao Beni, na Bolívia. O projeto nunca foi concluído, provavelmente por causa da proclamação da República que teria inviabilizado suas negociações políticas, mas serve como um exemplo das vantagens que Labre almejava com seu empreendimento.

No processo de classificação das populações indígenas do Purus, além dos povos sobre os quais tece comentários, Labre (1872, p. 30) ainda registra alguns nomes que eram utilizados para identificar alguns supostos povos indígenas no Purus. Esses nomes podem, na verdade, estar fazendo referência a diferenciações internas de um mesmo povo ou a etnônimos dados por um povo a outro. Dos dezesseis etnônimos listados, pelo menos seis dizem respeito aos Apurinã, a saber: Auainamary (Wainamary, sucuri), Cujigenery (Kuxĩkenyry, ?), Cigananery (Xĩkãnanyry, povo do tucano), Xiapuriniry (Xuapurinyry, um dos dois clãs Apurinã), Miriximandy (Miritimãty, povo do caititu ou um dos dois clãs Apurinã), Ximaniry (Ximãnyry, povo do peixe). A palavra niry (ou nyry) em Apurinã pode ser traduzido por pai. Como um sufixo, é utilizado para designar um grupo ou povo que possui relações de parentesco entre si. Esses etnônimos registram, portanto, o ponto de vista do povo Apurinã sobre si mesmo e sobre outros grupos indígenas com os quais mantinham alguma relação. Eles estão fazendo referência às subdivisões familiares e aos clãs Xuapurinyry e Miutymãnety.

Se esse escrito de Labre, produzido como um panfleto com claras intenções comerciais estratégicas, pode ser classificado quanto a suas informações como de segunda mão - mas nem por isso menos importantes -, o mesmo não se pode dizer de dois outros escrito de sua autoria datados de 1888. Trata-se de uma viagem de exploração entre os rios Madre de Deus e Acre (LABRE, 1888a) e de um relato sobre suas explorações ao Ituxi (LABRE, 1888b). Nessa época, Labre já contabilizava mais de uma década e meia de experiência e conhecimento em relação aos povos indígenas do Purus e seus afluentes. No entanto, as duas palestras ainda foram proferidas com claras intenções pessoais. Como já afirmei acima, Labre estava no Rio de 
Janeiro para defender que o governo imperial deveria desistir da proposta de construção de uma estrada de ferro no Rio Madeira para em vez disso investir em seu projeto de fazer da povoação de Lábrea o eixo econômico de uma estrada de ferro que ligaria o Rio Beni na Bolívia ao Rio Purus e daí ao Médio Rio Madeira (LABRE, 1888ª , p. 103). O relato sobre sua viagem é rico em informações sobre os povos indígenas e sobre os índios com os quais entra em contato e dos quais recebeu ajuda durante sua viagem. É possível, por exemplo, entrever os interesses indígenas ao servirem de guia em troca de "ferramentas, roupas, missangas e outras teteias" ou quando os índios de uma maloca ameaçam de morte o cacique Cunuparo que estava servindo de guia "por haver conduzido gente branca inimiga!" (LABRE, 1888a , p. 113).

Sobre os Apurinã e sobre os povos do Médio Purus, no entanto, a única informação é referente a origem do nome do Rio Acre que seria procedente da língua apurinã, Uakíry. Também lembra que na língua dos Paumari o nome do Rio Purus seria Wainy (LABRE, 1888 p. 102). Parece que Labre defende aqui a ideia de que o nome compartilhado entre os diferentes povos do Purus proveria do povo Paumari, uma vez que os Apurinã dariam o nome de Wéni e os Manchineri, por sua vez, o chamariam Weni (CHANDLESS, 1866 ${ }^{\mathrm{a}}$, p. 118). No entanto, é mais provável que a palavra seja de origem Apurinã ou pelo menos Aruak já que os Manchineri também o nomeiam da mesma forma e eles só eram encontrados ao sul do território Apurinã, enquanto os Paumari estavam ao norte. Assim, os povos Arawá teriam recebido a palavra de empréstimo dos Apurinã. A palavra atual dos Apurinã para o Rio Purus ainda continua sendo Wene e outros rios da região também são nomeados a partir desse substantivo como os rios Seruini (Siriwene), Pauini (Pawene), Inauini (Inawene) e Água Preta (Chiwene, hoje esse igarapé é conhecido pelos Apurinã como Yauruwa). Além do mais a palavra wainy também pode ser encontrada em apurinã, por exemplo: na formação do substantivo wainamary (sucuri), o que também indicaria uma relação com o rio já que a sucuri é um animal que vive na água.

A segunda palestra de Labre, na qual descreve suas expedições ao Rio Ituxi durante as décadas de 1870 e 1880, ao contrário da primeira, traz muito mais informações relevantes a respeito dos Apurinã, porque o Rio Ituxi corta todo o território tradicional apurinã (LABRE, 1888b, p. 117). Labre diz que o nome do rio viria dos Cathauichi (Catauixi). Alguns Apurinã o chamam atualmente de Tuxini. Na sua cabeceira, o rio recebe o nome de Iquiri (Ikyry), nome que provém da língua apurinã e guarda estreitas relações com o nome do Rio Acre (Akyry). Os principais afluentes da margem direita seriam os igarapés Huakery, Curekethé (Curueteté), Capsuryquy, Panicyny (Punicini) e Pucyary; já os da margem esquerda seriam o Entimary (Endimari), Hyurenen, 
Manghutery (Mangutiri) e Anguytheary. Labre também computa que, em 1888, a população nãoindígena do Ituxi seria em torno de 200 indivíduos, ao passo que os indígenas seriam perto de 8.000 mil, divididos em dez nações diferentes. No Rio Purus e seus afluentes, Labre acreditava ter em torno de 40 mil indígenas que falariam mais de 40 dialetos diferentes. No Ituxi, as nações mais numerosas seriam os Cachahary (Kaxarari), Canamary (Kanamari), Guarayos, Ipurynan (Apurinã). Outros povos como os Pamary (Paumari), Pamanah, Cathauixy (Catauixi) e Xyumah estariam, segundo Labre, fadadas ao desaparecimento, pois eram em pouco número e sofriam com doenças e perseguições dos outros grupos. Labre ainda afirma que, nas cabeceiras do Rio Ituxi, encontrou uma rede de estradas e caminhos servidas por taperas. Essas taperas eram casas simples nas quais os transeuntes pernoitavam. Conclui então que a região deveria ser muito povoada. (LABRE, 1888b, p. 118, 120).

Sobre os Apurinã, propriamente dito, o relato de Labre deixa entrever que ele fazia uso de sua mão de obra numa relação de reciprocidade. Ele afirma que em sua última exploração ao Alto Ituxi, teria sido acompanhado por um cacique apurinã da maloca Manghuthery (Mãkuthery). Seu nome era Mapyothê (Mapyũty) e, juntamente com sua esposa, filhos e outros familiares, teria prestado "bons serviços na excursão". Labre ainda diz:

De sua maloca, em 1879, me fôra confiada a educação de três meninos ipurynans. Dos quaes se acha presente um delles, o qual foi baptisado com o nome de Ulysses, conservando por sobrenome Mangah, seu nome primitivo de selvagem; sabe ler e escrever, é inteligente e de physionomia agradável, e apresento elle ao illustre auditorio como um tipo de sua nação e raça (LABRE, 1888 b, p. 120).

Como a fala de Labre deixa entrever, ele mantinha uma relação de compadrio com as famílias apurinã dessa aldeia. Semelhante aos missionários anglicanos e aos outros exploradores da região, ele também entrou no eixo de adoção e "comércio dos inocentes". No entanto, a fala vai mais além, pois Labre faz questão de apresentar ao grande público um desses jovens que estaria presente com ele perante a Sociedade Geográfica do Rio de Janeiro. Renomeado Ulysses, o jovem conservava seu nome apurinã, Mangah (Mãka). O nome lembra outro menino proveniente do Tumiã e adotado por um grupo de missionários anglicanos em 1881, Mainga (Maĩka ou Maỹka). Talvez poderia ser o mesmo menino adotado pelos missionários e que, após o fechamento da missão em 1883, teria permanecido trabalhando sob as ordens de Labre. Nesse caso, a data de 1879 dada por Labre seria relacionada aos outros dois rapazes que também estariam sob sua tutela. A suspeita aumenta quando o próprio Labre diz que Mãka sabia ler e escrever. Ora, muito provavelmente o único lugar no qual um apurinã 
poderia ter sido educado nas artes das letras naquele período seria indubitavelmente na escola da missão protestante. Além do mais Labre não diz como nem onde o rapaz teria aprendido a ler e a escrever e também não faz menção aos outros dois apurinã que estariam sob sua tutela. Provavelmente, eles não possuíam as mesmas habilidades intelectuais. Mesmo que não se trate do mesmo rapaz, o nome Mãka é, pois ainda, revelador das próprias intenções indígenas no processo de doação de crianças. Como argumentei acima, mãka é um adjetivo apurinã para designar algo que não presta, que está estragado ou que não é bom. O nome estaria indicando assim o ponto de vista dos Apurinã, ou seja, o menino poderia ser alguém sem uma rede familiar adequada ou que sobre ele pesasse algum tabu; lembrando que, para os Apurinã, o casamento correto é entre os dois troncos Xuapurinyry e Miutymãnety. Assim, como fruto de uma relação tida como incestuosa o menino poderia ser rejeitado socialmente.

Ao concluir sua palestra, retoma mais uma vez seu projeto implorando "ao Governo Imperial providências em favor da catechese dos selvagens, que extraviados pela vida nômade e errante que levam, não podem aproveitar a sociedade e menos a humanidade" (LABRE, 1888b, p. 120). Assim, Labre buscava garantir apoio tanto da Igreja quanto do Estado para viabilizar economicamente seu projeto colonialista. O apoio do Estado viria a partir do financiamento de uma estrada de ferro e garantiria o futuro econômico da povoação de Lábrea e a presença da Igreja estruturaria e consolidaria seu empreendimento.

\section{Conclusão}

Ao analisar as fontes históricas que tratam sobre os primeiros anos de colonização do Purus e sobre os Apurinã, cheguei à conclusão que existe um conjunto de fontes indispensáveis e outras que trazem informações circunstanciais, mas não menos importante. Essas fontes são os documentos produzidos pelas primeiras expedições de reconhecimento do Rio Purus, a saber, a expedição de João Henrique de Matos, a expedição de João Wilkens de Mattos e as expedições de Manuel Urbano, Salgado, Coutinho, Chandless, Labre, Ehrenreich e Steere. Manuel Urbano e Labre se destacam por serem também colonizadores. De todas as fontes em questão, aquela que melhor conhecia o Purus, seus afluentes e os povos indígenas que ali habitavam era, sem sombra de dúvida, Manuel Urbano. Esse caboclo afrodescendente serviu de informante para praticamente todos os demais exploradores e, inclusive dominava várias línguas indígenas, em especial a língua apurinã. Já os trabalhos de Ehrenreich e Steere são 
fontes muito importantes, mas que não foram aqui analisadas devido ao limite de laudas. Diferente das demais fontes, elas destacam-se por serem produções etnográficas, propriamente dito. Há que se dizer ainda que o material produzido pelos missionários da South American Missionary Society entre as décadas de 1870 e 1880 são também fonte de suma importância. No entanto, pelo mesmo motivo das fontes etnográficas, não foram aqui analisados.

\section{Referências}

BOCCARA, Guillaume. Fronteras, mestizaje y etnogénesis en las Américas. In: MANDRINI, Raúl J.; PAZ, Carlos D. (Org.). Las fronteras hispanocriollas del mundo indígena latinoamericano el los siglos XVIII-XIX: Un estudio comparativo. Argentina: Tandil, 2003. p. 63-93.

CASTELO BRANCO, José Moreira Brandão. Acreania. Revista do Instituto Histórico e Geográfico Brasileiro. Vol. 240, p. 3-83, Rio de Janeiro, 1958.

CHANDLESS, Willian. Ascent of the River Purûs. Journal of the Royal Geographical Society of London. Vol. 36, p. 86-118, 1866a.

CHANDLESS, Willian. Notes on the River Aquiry, the principal affluent of the River Purûs. Journal of the Royal Geographical Society of London. Vol. 36, p. 119-128, 1866 b.

COUTINHO, João Martins da Silva. Account of Manuel Urbano"s ascent of the Mucuim and Ituxý, tributaries of the Purûs, translated from Dr. Coutinho "es official Report to the Brazilian Government (1865). In: CHANDLESS, Willian. Notes on the River Aquiry, the principal affluent of the River Purûs. Journal of the Royal Geographical Society of London. Vol. 36, p. 119-128, 1866 [1865]. p. 126-128.

COUTINHO, João Martins da Silva. Considerações gerais sobre os rios que descem da cordilheira dos Andes nas proximidades de Cuzco, cachoeiras do Purus e Juruá. $1^{\circ}$ de março de 1863. In: O tratado Brasil-Peru: Documentos para a História do Acre. Brasilia: Senado Federal, 2009d [1863]. p. 253-299.

COUTINHO, João Martins da Silva. Relação dos lagos, rios, barreiras, casas e rochedos, que se encontram no Purus, da foz às barreiras de Jutanaham, segundo a ordem de subida. . In: $O$ tratado Brasil-Peru: Documentos para a História do Acre. Brasilia: Senado Federal, 2009a [1863]. p. 203-243.

COUTINHO, João Martins da Silva. Relatório a Manuel Clementino Carneiro da Cunha, presidente da Província do Amazonas, informando sobre a viagem de exploração do Rio Purus, desde sua foz até as barreiras de Hiutanahãn. Manaus, 8 de abril de 1862. In: $O$ tratado BrasilPeru: Documentos para a História do Acre. Brasilia: Senado Federal, 2009b [1862]. p. 179200. 
COUTINHO, João Martins da Silva. Relatório a Manuel Clementino Carneiro da Cunha, presidente da Província do Amazonas, informando sobre o Rio Purus. Manaus, 08 de abril de 1862 (Ofício). In: O tratado Brasil-Peru: Documentos para a História do Acre. Brasilia: Senado Federal, 2009c [1862]. p. 247-249.

CUNHA, Euclides da. À margem da história. Obra póstuma. Rio de Janeiro: Fundação Biblioteca Nacional, 1909. Disponível online: <http://bndigital.bn.br>. Acessado em: 26/07/2015.

CUNHA, Euclides da. Peru versus Bolívia. São Paulo: Cultrix, 1975 [1907]. Disponível online: $<$ http://www.bibvirt.futuro.usp.br>. Acessado em: 20/07/2015.

CUNHA, Euclides da; BUENÃNO, Pedro. Carta do Rio Purus. Rio de Janeiro: [s.n.], 1905. Disponível online: 〈http://bndigital.bn.br>. Acessado em: 26/07/2015.

EHRENREICH, Paul. Beiträge zur völkerkunde Brasiliens. Belin: Verlag von W. Spemann, 1891.

EHRENREICH, Paul. Viagem nos rios Amazonas e Purús. Revista do Museu Paulista. Vol XVI, São Paulo, p. 277-312, 1929.

FARAGE, Nádia. As muralhas dos sertões. Rio de Janeiro: Paz e Terra/ANPOCS, 1991.

FAULHABER, Priscila; MONSERRAT, Ruth (Orgs.). Tastevin e a etnografia indigena: coletânea de traduções de textos produzidos em Tefé (AM). Rio de Janeiro: Museu do Índio, 2008 .

KODAMA, Kaori. Os índios no Império do Brasil: A etnografia do IHGB entre as décadas de 1840 e 1860. Rio de Janeiro: Fiocruz, São Paulo: Edusp, 2009.

LABRE, Antonio Rodrigues Pereira. Exploração do Rio Ituxy. Revista da Sociedade de Geografia do Rio de Janeiro. Tomo IV, $2^{\circ}$ Boletim, p. 117-120, $1888 \mathrm{~b}$.

LABRE, Antonio Rodrigues Pereira. Rio Purus: Notícias. Maranhão: Tipografia do Paiz Imp. M. F. V. Pires, 1872.

LABRE, Antonio Rodrigues Pereira. Viagem exploradora do Rio Madre de Deus ao Acre. Revista da Sociedade de Geografia do Rio de Janeiro. Tomo IV, $2^{\circ}$ Boletim, p. 102-116, 1888a.

LAZARIN, Marco Antônio. A descida do Rio Purus: uma experiência de contato interétnico. Dissertação de Mestrado. Brasília: UNB, 1981.

LINK, Rogério Sávio. Vivendo entre mundos: o povo Apurinã e a última fronteira do Estado brasileiro nos séculos XIX e XX. Tese de doutoramento. Porto Alegre: UFRGS, 2016.

MATOS, João Henrique de. Relatório do estado de decadência em que se acha o Alto Amazonas. Revista do Instituto Histórico e Geográfico Brasileiro. Vol. 325, Out.-Dez., Brasília, Rio de Janeiro, p. 143-180, 1979 [1845]. 
MATTOS, João Wilkins de. Alguns esclarecimentos sobre as missões da província do Amazonas. Revista do Instituto Histórico e Geográfico Brasileiro. Vol. XIX, n. 21, Rio de Janeiro, p. 124-131, 1856 [1855].

MEIRELES, Denise Maldi. Guardiães da fronteira: Rio Guaporé, século XVIII. Petrópolis: Vozes, 1989.

NIMUENDAJÚ, Curt. Mapa etno-histórico do Brasil e das regiões adjacentes. (1981 [1944]). Disponível em: 〈http://biblio.etnolinguistica.org>. Acessado em: 10/11/2012.

NIMUENDAJÚ, Curt. Vocabularios Makusí, Wapicána, Ipurinã e Kapisanã. In: Journal de la Société des Américanistes. Tome 44, 1955. p. 179-197. Disponível em: <http://biblio.etnolinguistica.org >. Acessado em: 10/11/2012.

SALGADO, Serafim da Silva. Relatório sobre a exploração do Rio Purus. In: Fala dirigida a assembléia legislativa da província do Amazonas, no dia $1^{\circ}$ de outubro de 1853 pelo presidente da província, o conselheiro Herculano Ferreira Pena. Barra do Rio Negro: Tipografia de M. S. Ramos, 1853.

SAMM (South American Missionary Magazine). Anos 1873-1890. Londres.

SILVA, Hiram Reis e. Desafiando o rio-mar: descendo o Solimões. Porto Alegre: EDIPUCRS, 2010.

URBANO DA ENCARNAÇÃO, Manoel. Carta sobre costumes e crenças dos índios do Purús, dirigida a D. S. Ferreira Penna. In: Boletim do Museu Paraense de História Natural e Ethnographia, s.l.: Museu Paraense de História Natural e Ethnographia, v. 3, n. 1-4, anos 19001902, p. 94-97, 1902. Disponível online: 〈https://archive.org>. Acesso em: 26/08/2015.

VILAÇA, Aparecida. Quem somos nós: Os Wari’ encontram os brancos. Rio de Janeiro: UFRJ, 2006.

WALLIS, Gustav. Nachlaas von P. Petersen. Die Paumarys. Das Ausland. 14, Stuttgarte, 4 de abril de 1886.

Recebido em: 23/01/2017 Aprovado em: 05/03/2017 